\title{
蛍光ランプの異なる色温度が明るさ知覚に及ぼす影響 THE EFFECT OF DIFFERENT COLOUR TEMPERATURE OF FLUORESCENT LAMPS ON BRIGHTNESS PERCEPTION
}

\author{
尹 仁*, 堀越 哲美**, 宮本征一*** \\ Yoon In, Tetsumi HORIKOSHI and Seiichi MIYAMOTO
}

\begin{abstract}
The objective of this paper is to clarify the effect of spectral power distribution of different fluorescent lamps on the human brightness perception in a building interior. The following psychological tests were conducted: The warm white, daylight and 3band-type fluorescent lamps were used as lighting sources. The 22 subjects compared lit environments of a pair of rooms. One was lit by daylight fluorescent lamps and the other room was lit by the warm white or 3band-type fluorescent lamps, respectively, at three luminance level : 100,200 and $300 \mathrm{~cd} / \mathrm{m}^{2}$. After the subjects judged the brighter room, they adjusted one side to get equal brightness with the other. At that condition luminance data of two rooms were recorded. Ratios of luminance by the compared lamp to that by daylight lamp were calculated. For all subjects, the ratios 1.22 and 1.03 were determined for the warm white and 3band-type fluorescent lamps, respectively, to obtain the equal perceived brightness at luminance level $100 \mathrm{~cd} / \mathrm{m}^{2}$. The ratio decreases with a rise in luminance level.
\end{abstract}

Keywords : building interiors, fluorescent lamp, luminance, brightness perception, colour temperature, colour rendering

室内空間，蛍光ランプ，輝度，明るさ知覚，色温度，演色性

\section{1.はじめに}

視環境の中で，照明は大きな役割を持っている。この 視環境の快適性に関連して, 照度, 光源, 照明方式など の照明条件は明るさ知覚に大きな影響を及ぼしていると 考之られる。特に，照明されている光源の特性すなわち， 光源によって異なる分光分布があり，それによって光の 色，色温度そして演色性などに違いがある。測光学的に は等しく照射されていても実際感じる明るさ知覚は必ず しも等しくはなく，明るさ知覚に及ぼすこれら特性の影 響に関する研究は多数報告されてきた。Aston ら ${ }^{1} は$ 室 内の明るさを視覚の明瞭さとしてとらえる観点から実験 を行い，光源の演色性の差異による物体色の見之の違い の効果を照度レベル別に明らかにした。中村ら²は光の 色の相異が明るさ感に及ぼす影響の定量化を様々な蛍光 灯を用いて試みた。その他には，視対象物がある場合， 明るさ感の評価基準が異なる場合または光源の異なる演 色性による物体色の見之を扱った研究家出などがあり，同 様の結果を得ている。
しかし；次のような問題を検討する必要があると考之 られる。

(1)今までの研究で扱われている光源の特性の違いによる 有彩色物体から受ける心理的印象の差は, 明るさ感の 違いではなく，物体色間から受ける感情の違いである という指摘5である。

ここでは明るさ知覚というのは, 人間が光を出す対象, また光を反射あるいは透過する対象を見た時に，視覚系 がその明暗に関して知覚することであり，対象の輝度だ けではなく, 対象の色, 周囲の輝度及び色との対比など にも依存するという定義的に従う立場をとるものとす る。納谷ららの指摘しているよjに, 従来の研究には, 明 るさ知覚はそれに見られる視对象物の形状や色及びその 対比などから受ける明瞭感や満足感であるとしているも のもあるが，この考え方とは異なるものであるとし，著 者らは，この観点から研究を行っている。河合7も，明る さの判断の際に，ピントの調節などの作用が関与する見 え方をする場合は，その分だけ判断の材料となる情報が
* 名古屋工業大学大学院社会開発工学尃攻 大学院生・工修

** 名占屋工業大学社会開発工学科 教授・工博

*** 名古屋工業大学社会開発工学科 助手・修士 (工学)
Graduate Student, Dept. of Architecture, Nagoya Institute of Technology, M. Eng.

Prof., Dept. of Architecture, Nagoya Institute of Technology, Dr. Eng. Research Assoc., Dept. of Architecuture, Nagoya Institute of Technology, M. Eng. 
多くなり，判断が複合的で不明確となるため，明るさを なるべく純粋に捉えたいと思うならば，表面色の見え方 は避けて，開口色（面色）の見え方の刺激光を用いるべ きであると述べている。以上のように，光源が発する光 に対する明るさ知覚の評価は，広視野の白色で仕上げた 観察面を作ることによって光源から発した光が反射して 開口色（面色）の見え方の刺激光になるようにして行う ことが必要と考えられる。このような方法による研究は まだ十分に研究されていないと考之られる。

(2)室内において, 光源の色温度と照度レベルが異なるこ とによる人間の感情の変化については多数報告8)され ているが，光源の特性と明るさ知覚との関係を前述の 開口色の見え方による方法で輝度レベル別に検討した 研究も，まだ十分ではないと考えられる。

そこで, 本研究では上記の問題点に基づき, 室内空間 が異なる蛍光ランプで照明されている場合, 色温度と演 色性など光の諸特性が異なることが輝度レべル別に明る さ知覚にどのように影響するかを既存の結果と比べ，考 察する。これは人間の心理的反応を知ることにより, 望 ましい照明条件を把握して視環境の設計や評価に対し て，適用できる基礎的な資料を提供するものになると考 えられる。そのために $100 \mathrm{~cd} / \mathrm{m}^{2} か ら 300 \mathrm{~cd} / \mathrm{m}^{2}$ の輝度レ ベルにおいて， 3 種の蛍光ランプを用いて，以下のよう な心理実験を行った。

\section{2，実験計画}

\section{2-1 実験装置}

図 1 に示すように無空の実験室内に大きさの等しい誢 き空 $(1200 \times 700 \mathrm{~mm})$ を持つ A 室と B 室の 2 つの実験 ブースを設けた黒色の布製実験空間を設け，実験に用い た。2つの実験ブース内は波長420から780nm までのほ ぼフラットな反射特性を持つ, つや消し白色ペイントで 仕上げた。照明器具は困1に示すように, 被験者の観察

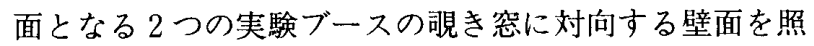
らし，その壁面の輝度分布ができるだけ一様になるよう に設置した。その観察面での反射光を誢き窓を介して被
験者に提示することとした。実験の光源は表 1 の一般に 市販されている 3 種の $40 \mathrm{~W}$ の监光ランプを使用した。 2 つのブース $\mathrm{A}$ 室と $\mathrm{B}$ 室の観察面の輝度レベルは調光器 によって被験者が調整できるようにした。図 2 に光波長 分析計（ライカ, LI1800）を用いて測定した各蛍光ラン プから発する光及び観察面での反射光の分光分布を示 す。蛍光ランプからの光と反射光の分光分布を比較する と, 蛍光ランプによっては $410 \mathrm{~nm}$ 以下の波長で光源から の光と反射光の間に多少差があるものもあった。調光に よる分光分布の変化はほとんど見られなかった。観察面

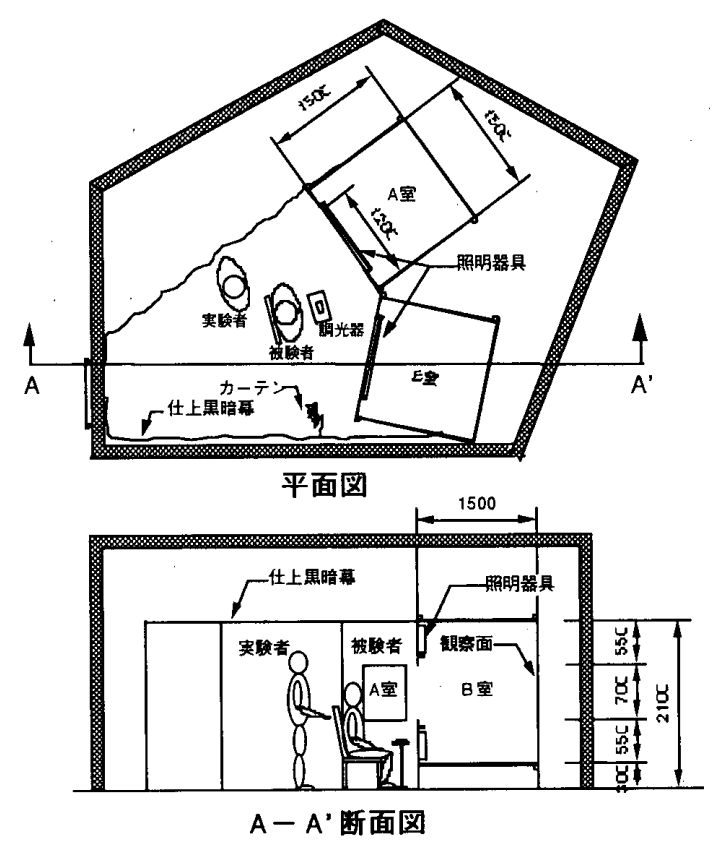

図 1 実験室の概要

表 1 実験光源に用いた蛍光ランプ

\begin{tabular}{|c|c|c|c|}
\hline $\begin{array}{c}\text { 蛍光ランプの種颣 } \\
\text { 記号 }\end{array}$ & & \multicolumn{2}{|c|}{$\begin{array}{cc}\text { 色温度 } & \text { 平均演色評価数 } \\
\mathrm{K} & \mathrm{Ra}\end{array}$} \\
\hline 冝光色蛍光ランブ & $: \mathrm{DL}$ & 6500 & 74 \\
\hline 温白色蛍光ランプ & : ww & 3500 & 60 \\
\hline 3波長城発光形蛍光ラン & プ : $\mathrm{Pa}$ & 5000 & 88 \\
\hline
\end{tabular}
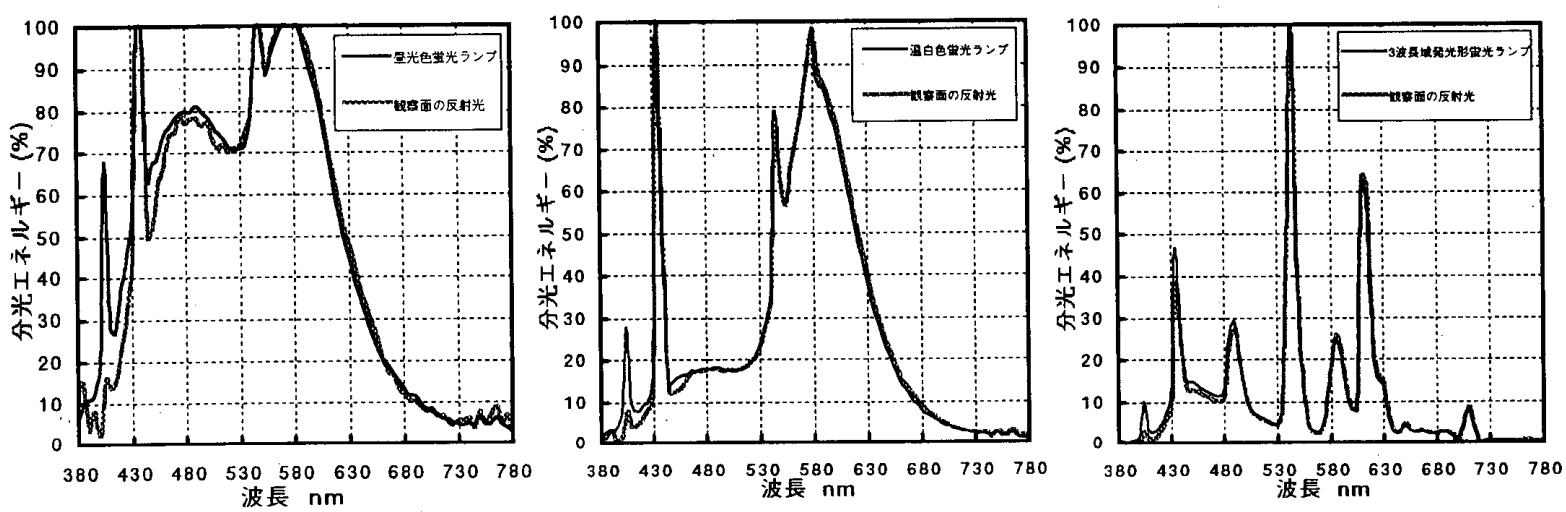

図 2

実験光源の分光エネルギー分布 
表 2 観察面の反射光の輝度レベル別の色度座標

\begin{tabular}{|c|c|c|c|c|}
\hline \multirow[t]{2}{*}{ 実験光源の種類 } & \multirow{2}{*}{\begin{tabular}{|c|} 
彈度レベル \\
$c d / \mathrm{m}^{*}$
\end{tabular}} & \multicolumn{2}{|c|}{ 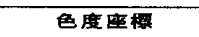 } & \multirow{2}{*}{$\begin{array}{c}\text { 色温度 } \\
k\end{array}$} \\
\hline & & $x$ & $y$ & \\
\hline \multirow{3}{*}{ 量光色蚠光ランプ } & 100 & 0.334 & 0.355 & 5433 \\
\hline & 200 & 0.333 & 0.355 & 5433 \\
\hline & 300 & 0.334 & 0.354 & 5429 \\
\hline \multirow{3}{*}{ 温白巴学光ランプ } & 100 & 0.429 & 0.398 & 3170 \\
\hline & 200 & 0.427 & 0.397 & 3126 \\
\hline & 300 & 0.427 & 0.397 & 3144 \\
\hline \multirow{3}{*}{$\begin{array}{r}\text { 3波長域発光形 } \\
\text { 蛍光ランプ }\end{array}$} & 100 & 0.357 & 0.366 & 4635 \\
\hline & 200 & 0.357 & 0.365 & 4666 \\
\hline & 300 & 0.356 & 0.363 & 4684 \\
\hline
\end{tabular}

表 38 つの標準色票に対する輝度レベル別の色票座標の変化

\begin{tabular}{|c|c|c|c|c|c|c|c|c|c|c|}
\hline & \multicolumn{3}{|c|}{ 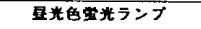 } & \multicolumn{3}{|c|}{ 蛊白色䖝光ランプ } & \multicolumn{3}{|c|}{ 3波莀抹形监光ランフ } \\
\hline & & 300 & 160 & 50 & 00 & 150 & 50 & 300 & 150 & 50 \\
\hline \multirow[t]{2}{*}{$10 P 6 / 8$} & & 321 & 0.319 & 0.319 & 411 & 0.414 & 0.430 & 0.320 & 0.318 & 0.320 \\
\hline & & & 28 & 0.28 & 64 & 0.363 & 0.352 & 265 & 0.264 & 0.264 \\
\hline \multirow[t]{2}{*}{$2.5 \mathrm{P} 6 / 8$} & $x$ & 297 & 0.297 & 0.297 & 392 & 0.392 & 0.391 & 0.278 & 0.275 & 0.279 \\
\hline & $y$ & 0.301 & .300 & 0.306 & 59 & 0.357 & 0.358 & 0.259 & 0.254 & 0.253 \\
\hline \multirow[t]{2}{*}{$6 \mathrm{~PB} 6 / 8$} & $x$ & 279 & 0.277 & 0.279 & 340 & 0.339 & 0.338 & 0.258 & 0.256 & 0.239 \\
\hline & & - & 0.298 & 0.297 & 30 & 0.327 & 0.329 & 0.269 & 0.266 & 0.265 \\
\hline \multirow[t]{2}{*}{$10 B G 8 / 4$} & x & 0 & 0.294 & 0.297 & .372 & 0.368 & 0.366 & 0.284 & 0.281 & 0.284 \\
\hline & & .340 & 0.337 & 0.337 & 1.386 & 0.384 & 0.385 & 0.321 & 0.321 & 0.318 \\
\hline \multirow[t]{2}{*}{$2.5 \mathrm{G6} / 6$} & $x^{x}$ & 0.312 & 0.311 & 0.311 & 0.389 & 0.395 & 0.392 & 0.287 & 0.286 & 0.288 \\
\hline & & .375 & 0.373 & 0.369 & .438 & 0.430 & 0.435 & 0.385 & 0.381 & 0.383 \\
\hline \multirow[t]{2}{*}{$5 \mathrm{GY} 6 / 8$} & x & 0.367 & 0.037 & 0.367 & 443 & 0.443 & 0.442 & 0.346 & 0.345 & 0.349 \\
\hline & & 0.6 & 0.474 & 0.471 & 0.483 & 0.481 & 0.481 & 0.465 & 0.462 & 0.465 \\
\hline \multirow[t]{2}{*}{$5 Y 6 / 4$} & x & 0.36 & 0.341 & 0.346 & 0.442 & 0.442 & 0.440 & 0.334 & 0.334 & 0.338 \\
\hline & $\underline{Y}$ & 0.388 & 0.394 & 0.380 & 0.418 & 0.414 & 0.415 & 0.358 & 0.359 & 0.360 \\
\hline \multirow[t]{2}{*}{$7.5 \mathrm{R6} / 4$} & $x$ & 0.343 & 0.343 & 0.343 & 0.447 & 0.446 & 0.446 & 0.334 & 0.333 & 0.337 \\
\hline & & 0.353 & 0.349 & 0.351 & 0.393 & 0.392 & 0.387 & 0.330 & 0.328 & 0.329 \\
\hline
\end{tabular}

の輝度測定は図 1 に示す被験者の観察位置で, 床面から $1.2 \mathrm{~m}$ の椅子に座った被験者の眼の位置から輝度計を用 いて測定した。被験者の主視線から $30^{\circ}$ 以内の視野での観 察面の輝度はほぼ一定であり，その平均值を被験者の視 野内の輝度の代表值とした。観察面と実験ブース内の他 の構成面との輝度差が15\%以内になるようにした。調光 による輝度レベル別のブース内の輝度分布はほぼ一定で あることを確認した。色彩輝度計 (TOPCON, BM-5A) を用い，実験光源に対して，輝度レベルの変化による蛍 光ランプから発する光及び観察面の反射光の色度と色温 度の変化を測定した。表 2 に観察面の反射光の輝度レべ ル別の色度座標及び色温度を示す。また平均演色性評価 数を求める 8 つ試験色 (JISの標準色票) を用いて, 輝 度レベルの変化による色票の色度の変化を测定した。表 3 はその結果である。いずれの場合にも，輝度レベルの 変化による色温度, 各色度はほとんど変化がないと判断 できるものと考えられる。

\section{2-2 実験条件と方法}

実験の条件を表 4 に示す。条件 1 から 8 までは観察面 の各輝度レベル $100 \mathrm{~cd} / \mathrm{m}^{2}, 200 \mathrm{~cd} / \mathrm{m}^{2}, 300 \mathrm{~cd} / \mathrm{m}^{2}$ の 3 段階 のレベルで行い, 条件 9 と条件 10 は $100 \mathrm{~cd} / \mathrm{m}^{2}$ と $300 \mathrm{~cd} /$ $\mathrm{m}^{2}$ の 2 段階の輝度レベルで行った。米印は基準になる側 の光源, 無印は調整する側の光源を示している。1 1 1 条件あたりの被験回数は 1 回である。

実験方法は昼光色蛍光ランプと温白色蛍光ランプある いは 3 波長域発光形蛍光ランプとの比較によって行っ
表 4 実験条件

\begin{tabular}{|c|c|c|}
\hline 条件 & A室光漟 & B室光源 \\
\hline 1 & 且光色蛍光ランプ & 温白色㖹光ランプ \\
\hline 2 & 冝光色蛍光ランブ & 温白色覓光ランプ \\
\hline 3 & 盗白色蛍光ランブ & 䒜光色當光ランブ \\
\hline 4 & 盜白色労光ランブ & 㫜光色覚光ランプ \\
\hline 5 & 昷光色営光ランブ & 3波長城発光形学光ランブ \\
\hline 6 & 冝光色蛍光ランブ & 3波長娍発光形学光ランプ* \\
\hline 7 & 3波長域発光形学光ランブ* & 昷光色當光ランブ \\
\hline 8 & 3波長城発光形労光ランブ & 且光色监光ランプ \\
\hline 9 & 冝光色贵光ランブ & 昷光色蛍光ランプ \\
\hline 10 & 淐白色省光ランブ & 温白色當光ランプ \\
\hline \begin{tabular}{|c|c|} 
度 \\
レペル
\end{tabular} & $\begin{array}{l}100 \mathrm{~cd} / \mathrm{m} \\
200 \mathrm{~cd} / \mathrm{m} \\
300 \mathrm{~cd} / \mathrm{m}\end{array}$ & \\
\hline
\end{tabular}

た。観察面を見る視覚は $10^{\circ}$ 以上になるようにした。被験 者は学生・大学教員で20から39歳までの男女22名とした。 尚，色覚異常者はない。

\section{2-3 実験手順}

実験空間の照明を消し，被験者を入場させ，椅子に座 らせる。被験者の前面にカーテンをひき，その効果は不 明であるが, $0.03 \mathrm{~cd} / \mathrm{m}^{2}$ 以下の輝度レベルで実験前ある いは前条件の残像をなくすために 2 分間の暗順応をさせ る。注)その後, カーテンを開けて実験条件の環境を提示す る。1 分30秒の間, 被験者は与之られた条件の A 室と B 室の明るさを比較する。その時，どちらが明るく感じる かを質問する。明るさに差があると感じれば，調光器で 他方と等しい明るさになるように比較側の輝度を調整す る。その時の両室の観察面の輝度を記録する。照明を調 整する実験ブースは 2 室を交互に変えて提示する。実験 ブースと実験室間の照明を消して，再げ被験者に 2 分間 の暗順応をさせ, 次の実験条件で上述の手順を繰り返す。 条件の提示は乱数表を用い, アトランダムに行った。

\section{3. 結果}

図 3 に被験者の口答による各実験条件での明るさの比 較結果を示す。昼光色蛍光ランプと温白色蛍光ランプと の比較では $100 \mathrm{~cd} / \mathrm{m}^{2}$ から $300 \mathrm{~cd} / \mathrm{m}^{2}$ との高い輝度レべ ルになるに従って $\mathrm{A}$ 室と B 室の観察面の明るさを等し く感じた人数が多くなった。被験者は 1 名を除き全輝度 レベルで昼光色蛍光ランプを温白色蛍光ランプより明る いあるいは同じと感じていた。 3 波長域発光形蛍光ラン

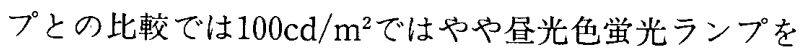
明るく感じていると答えた被験者が多かったが, 輝度レ ベルが高くなるにつれ，3波長域発光形蛍光ランプをよ り明るくまたは同じと感じる人数が多くなった。表 5 に 比較側の調整前輝度と調整後輝度の平均值と標準偏差 (SD) 及び両者の平均值の差の $\mathrm{t}$ 検定の結果を示す。昼光 色蛍光ランプと温白色蛍光ランプとの比較では条件 1 か ら条件 4 までのすべての条件で有意差が認められた。昼 光色蛍光ランプと 3 波長域発光形蛍光ランプとの比較で 
は, $300 \mathrm{~cd} / \mathrm{m}^{2}$ の輝度レベルと条件 6,7 の場合には有意 差が見られなかったが, $100 \mathrm{~cd} / \mathrm{m}^{2}$ と $200 \mathrm{~cd} / \mathrm{m}^{2}$ の条件 5 ，
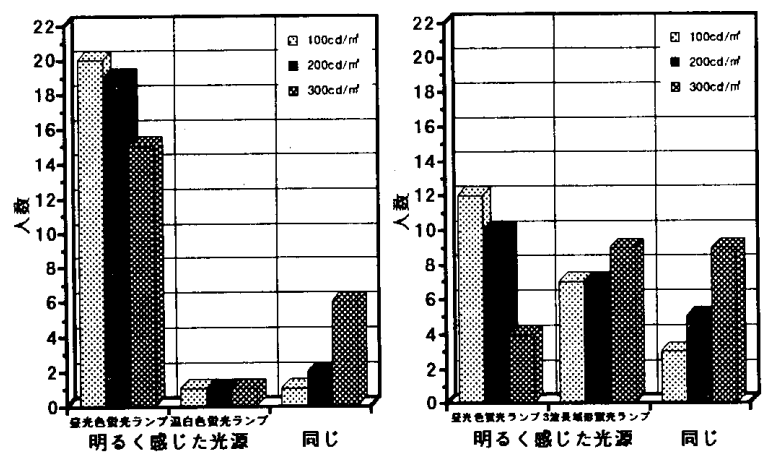

図3明るさ判断の結果

表 5 輝度の平均値の差の検定

(a) 昼光色蛍光ランプと温白色蛍光ランブとの比較

\begin{tabular}{|c|c|c|c|c|c|c|}
\hline \multirow[t]{2}{*}{ 実䀦采件 } & \multicolumn{2}{|c|}{ 两整前瀷度 $\mathrm{cd} / \mathrm{m}^{\circ}$} & \multicolumn{2}{|c|}{ 䣩整洤輝度 $\mathrm{cd} / \mathrm{m}^{\prime}$} & \multirow{2}{*}{\multicolumn{2}{|c|}{ t值 }} \\
\hline & 平均值 & SD & 平均值 & SD & & \\
\hline \multirow{5}{*}{$\begin{array}{l}100 \\
\mathrm{~cd} / \mathrm{m}^{\circ}\end{array}$} & 101 & 1.1 & 127 & 16.6 & -7.39 & ** \\
\hline & 101 & 1.5 & 86 & 13.0 & 5.63 & $* *$ \\
\hline & 101 & 1.2 & 88 & 12.1 & 4.81 & $* *$ \\
\hline & 100 & 1.3 & 124 & 16.1 & -6.56 & $* *$ \\
\hline & 100 & 0.9 & 102 & 5.5 & -0.16 & \\
\hline 10 & 100 & 4.7 & 101 & 1.5 & -1.07 & \\
\hline \multirow{4}{*}{$\begin{array}{l}200 \\
\mathrm{~cd} / \mathrm{m}^{\circ}\end{array}$} & 201 & 1.8 & 234 & 28.3 & -5.58 & $* *$ \\
\hline & 201 & 1.6 & 181 & 27.1 & 3.44 & $* *$ \\
\hline & 200 & 1.7 & 178 & 21.9 & 4.82 & $* *$ \\
\hline & 200 & 4.4 & 233 & 30.5 & -4.81 & $* *$ \\
\hline \multirow{6}{*}{$\begin{array}{c}300 \\
\mathrm{~cd} / \mathrm{m}^{\circ}\end{array}$} & 300 & 0.9 & 318 & 31.5 & -2.61 & $* *$ \\
\hline & 302 & 4.3 & 279 & 31.0 & 3.47 & $* *$ \\
\hline & 301 & 2.4 & 281 & 24.8 & 3.84 & $* *$ \\
\hline & 300 & 1.2 & 328 & 30.0 & -4.35 & 水皮 \\
\hline & 300 & 1.5 & 298 & 7.9 & 0.69 & \\
\hline & 300 & 2.9 & 297 & 9.1 & -1.18 & \\
\hline
\end{tabular}

(b) 冝光色蛍光ランプと 3 波長域発光形巣光ランブとの比較

\begin{tabular}{|c|c|c|c|c|c|c|}
\hline \multirow[t]{2}{*}{ 実魜条件 } & \multicolumn{2}{|c|}{ 画整前輝度 $\mathrm{cd} / \mathrm{m}^{\circ}$} & \multicolumn{2}{|c|}{ 閏整得耀度 $\mathrm{cd} / \mathrm{m}^{\circ}$} & \multirow{2}{*}{\multicolumn{2}{|c|}{ t值 }} \\
\hline & 平均值 & $S D$ & 平均值 & SD & & \\
\hline & 100 & 0.9 & 105 & 7.7 & -2.84 & $* *$ \\
\hline 100 & 100 & 0.8 & 99 & 11.5 & 0.34 & \\
\hline \multirow[t]{2}{*}{$\mathrm{cd} / \mathrm{m}^{\prime}$} & 100 & 1.2 & 104 & 15.3 & -1.09 & \\
\hline & 100 & 1.0 & 107 & 10.4 & -2.95 & $* *$ \\
\hline \multirow{4}{*}{$\begin{array}{l}200 \\
\mathrm{~cd} / \mathrm{m}^{\circ}\end{array}$} & 201 & 2.1 & 206 & 14.0 & -1.72 & $*$ \\
\hline & 200 & 1.2 & 198 & 15.0 & 0.59 & \\
\hline & 201 & 2.7 & 202 & 14.0 & -0.40 & \\
\hline & 200 & 1.2 & 208 & 17.0 & -1.99 & * \\
\hline \multirow{4}{*}{$\begin{array}{c}300 \\
\mathrm{~cd} / \mathrm{m}^{2}\end{array}$} & 301 & 1.6 & 301 & 13.6 & -0.11 & \\
\hline & 300 & 1.6 & 301 & 17.1 & -0.11 & \\
\hline & 300 & 1.7 & 297 & 14.2 & 1.17 & \\
\hline & 301 & 2.3 & 300 & 24.7 & 0.23 & \\
\hline
\end{tabular}

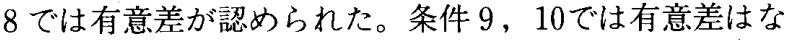
く $\mathrm{A}$ 室と B 室の両実験ブースで提示した光環境の間に バイアスがないことを示していると考えられる。図 4 と 図 5 に各条件の輝度レベル別に, 調整前の両室の輝度比 と両室を等価的な明るさになるように調整した後の輝度 比を示す。等価的な輝度比は昼光色蛍光ランプの輝度に 対する温白色営光ランプの輝度または 3 波長域発光形蛍 光ランプの輝度の比である。図 4 は各条件の平均値を示 している。昼光色蛍光ランプに対する比較光源の等価的 輝度比は全ての条件で 1 より大きい值となっている。温 白色蛍光ランプとの輝度比は 3 波長域発光形巣光ランプ

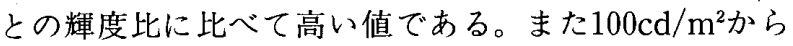

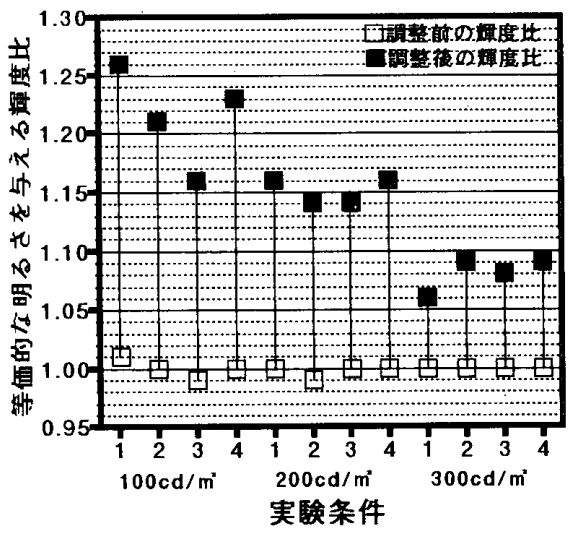

(a) 冝光色蛍光ランプと温白色蛍光ランプとの比較

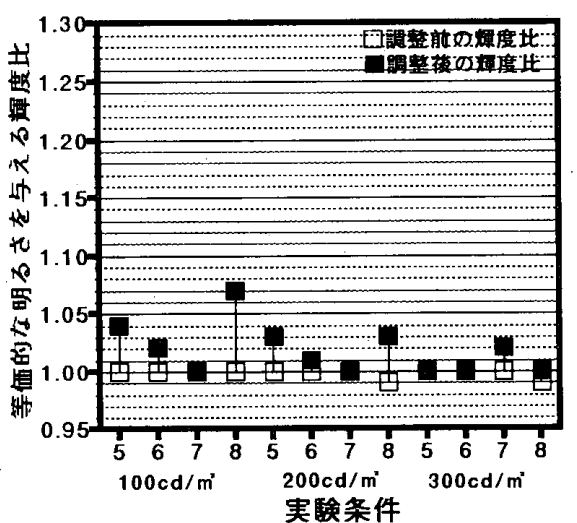

(b) 昼光色蛍光ランプと 3 波長域発光形蛍光ランプとの比較

図 4 等価的な明るさを与之る輝度比

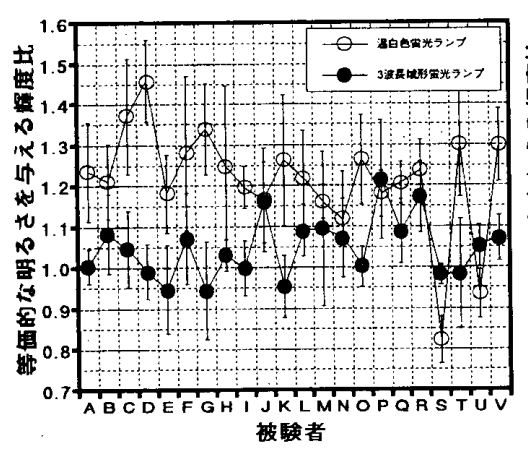

(a) $100 \mathrm{~cd} / \mathrm{m}^{2} の$ 場合

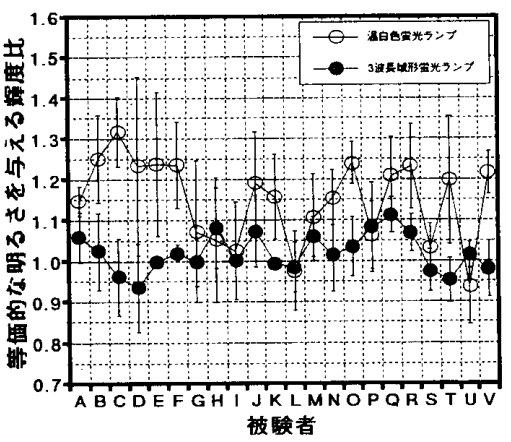

(b) $200 \mathrm{~cd} / \mathrm{m}^{2}$ の場合

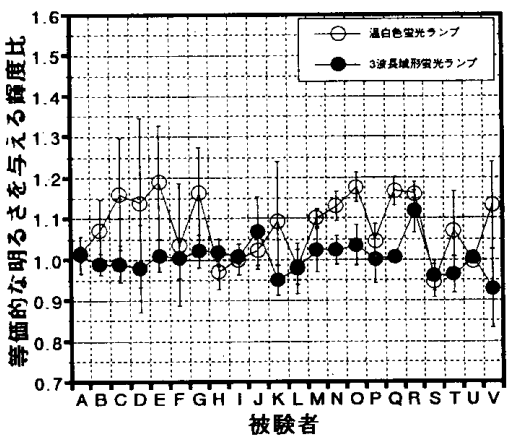

(c) $300 \mathrm{~cd} / \mathrm{m}^{2}$ の埸合

図 5 光源別, 輝度レベル別の等価的な明るさを与える輝度比の比較 
$300 \mathrm{~cd} / \mathrm{m}^{2}$ へと輝度レベルが高くなるに従って各条件の 等価的な明るさを与える輝度比は小さい值になってい く。図 5 は被験者別の昼光色蛍光ランプに対する各比較 光源に関する等価的な明るさを与える輝度比を示してい る。ここに示される輝度比は条件 1 から条件 4 まで，ま たは, 条件 5 から条件 8 までの実験で求められた輝度比 の平均値である。被験者 3 名 (P,S,U) を除いて, 等し い明るさを得るための輝度比は温白色蛍光ランプの場合 に大きく， 3 波長域発光形蛍光ランプの場合の方が 1 に 近い值となっている。図6に各実験条件から得られた等 価的な明るさを与える場合の昼光色蛍光ランプの輝度と 比較営光ランプの輝度の関係を示す。輝度レベルが上が るに従って等しい值に収束する傾向が見られる。

\section{4. 考察}

(1) 明るさ知覚と輝度レベル

等しい測光量下でも, 被験者が感じる明るさは蛍光ラ ンプの種別によって異なる結果か得られる。そして輝度 レベルによってもその影響の度合に差が見られる。堀越 ら ${ }^{9}$ は $40 \mathrm{~cd} / \mathrm{m}^{2}$ から $75 \mathrm{~cd} / \mathrm{m}^{2}$ までの低い輝度レベルで昼 光色蛍光ランプに対する温白色蛍光ランプの等価的な輝 度比は1.22以上であると報告した。これと同じ光源を用 いて行ったそれよりも高い輝度レべルで行った本実験で も，等価的な明るさ知覚を与之る昼光色蛍光ランプに対 する温白色蛍光ランプの輝度比は図 4 に示されるように 提示条件により1.16から1.26であり, 妥当な結果が得ら れたと考えられる。さらに高い輝度レベルになると, 明 るさ知覚の差は無くなっていくものと推察される。

(2) 明るさ知覚と色温度

図 7 に色温度と等価的な明るさを与える輝度比との関 係を示す。色温度の上昇によって等価的な輝度比が減少 している。Berman ら ${ }^{10}$ は色温度が高い光源が低い光源 より明るく感じられると述べた。本実験でも, 色温度の 高い光源を被験者は明るく感じていると考之られる。し かし, 中村らは3001x から9001x までの照度レベルでは， 色温度が高い 3 波長域発光形蛍光ランプは, 色温度が低 い温白色蛍光ランプと白色蛍光ランプに比べ, 明るく感 じられたと報告している。しかし， 3 波長域発光形蛍光 ランプとそれよりも色温度が高い昼光色蛍光ランプとの 比較では, $12001 \mathrm{x}$ の照度レベルにおいて等しい明るさに 感じ, より低い照度レベルでは 3 波長域蛍光ランプが明 るく感じられたと述べている。これは本実験の結果と少 し異なる結果となっている。湯尻ら ${ }^{11}$ は視对象物がある 場合に評定尺度法を使った実験を行い，照度が高い場合 には，高演色性形，普通形ともに低色温度の光源の明る さ感が他の光源と比較して低くなり, 低照度の場合には, その差がなくなるという, 本実験の結果とは測光量のレ ベルの影響に関して異なる傾向を示す結果を報告してい

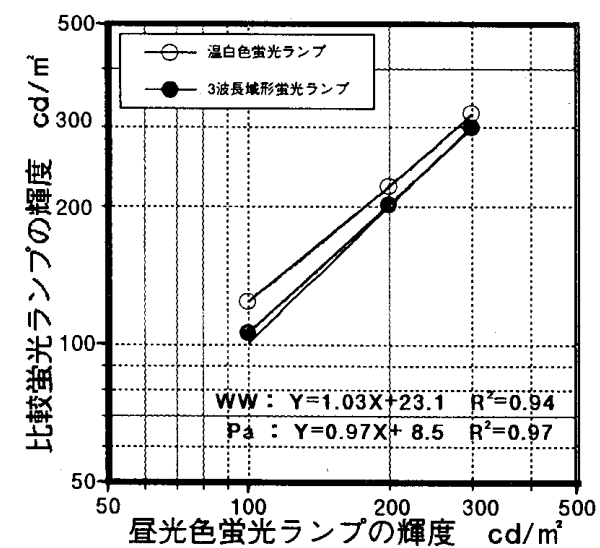

図 6 等価的な明るさを与之る輝度の関係

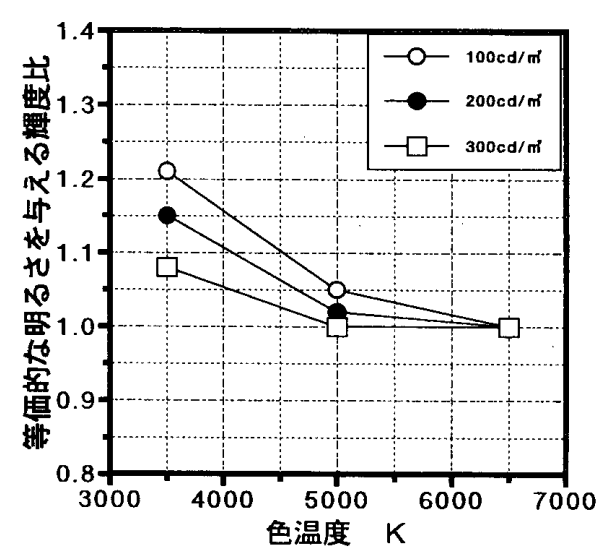

图 7 色温度と等価的な明るさを与える輝度比

る。これらの理由として，中村らの実験では，有彩色を 含む模型室を用いており, 湯尻らの実験では視对象物が あり，心理反応の測定方法も違うことによる結果である と考えられる。さらに，照度レベルが低くなるにつれ， 湯尻らの実験で用いられた R, YR 系の色彩は低明度に

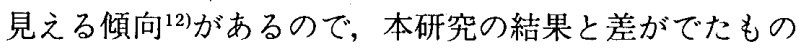
と考之られる。

(3) 明るさ知覚と演色性

図 8 に光源の平均演色性評価数と等価的な輝度比との 関係を示す。昼光色蛍光ランプと温白色蛍光ランプの間 では演色評価数の增加によって明るさ知覚の增加の関係 が見られたが, 昼光色蛍光ランプと 3 波長域発光形営光 ランプとの間では光源の演色評価数の増加によってよ り, 明るく知覚されるとは言之ないと考えられる。Aston ら"の実験では2001x から8001x へと照度レベルが高くな るにつれて, 演色性のよい光源が演色性の悪い光源に比 べて視覚の明暸さが $25 \%$ から $40 \% に$ 高くなると述べてい る。納谷ら $\left.{ }^{13}\right) は 125 \mathrm{~cd} / \mathrm{m}^{2}$ の輝度レベルで, 演色性が異な る蛍光ランプを用いて実験した結果, 有彩色サンプルが, 照明光の演色性の変化により高メトリッククルマに演色 され, 明るく知覚されたと述べ，白色の観察面を用い， 開口色として提示した本実験の結果と少し異なる結果と 


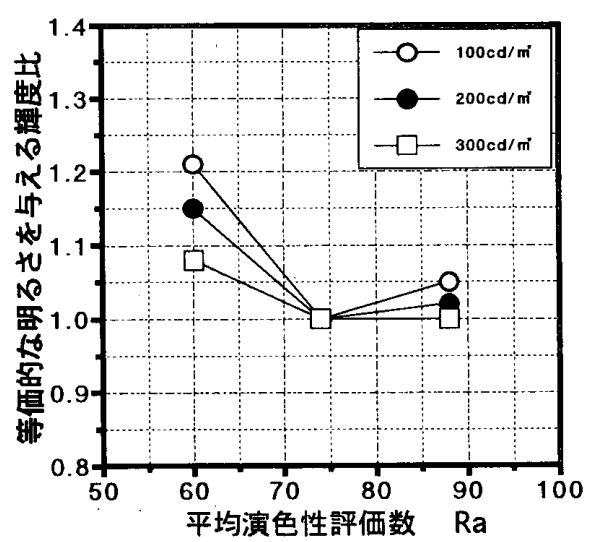

图 8

平均演色性評価数と等価的な明るさを与える輝度比

なっている。これは，視対象物として有彩色物体を用い た場合には光源の演色性が視覚の明瞭さを含めた明るさ 知覚に影響を与えることは期待できるが，視对象物の表 面色や形状などによる影響を無くした場合は，光源の演 色性は明るさ知覚に影響を及ばさないものと考之られる。

\section{5.まとめ}

本研究では, 蛍光ランプの特性である光色, 色温度, 演色性の違いに対する明るさ知覚の影響を調べるため に, $100,200,300 \mathrm{~cd} / \mathrm{m}^{2}$ の 3 段階の輝度レベル別に, 昼 光色蛍光ランプを基準として温白色蛍光ランプ及び 3 波 長域発光形蛍光ランプから発する光を白色壁面で反射さ せ開口色（面色）として提示し，等しい明るさを与える 輝度を求めるという心理実験を行い以下の結果を得た。

(1)既存の有彩色物体や表面色に対寸る明るさ知覚評洒の 研究結果のように, 等しい測光量下でも, 被験者が感 じる明るさ知覚は光源の違いによって異なった。実験 条件 $100 \mathrm{~cd} / \mathrm{m}^{2}$ から $300 \mathrm{~cd} / \mathrm{m}^{2}$ までの輝度レべルにおけ る昼光色蛍光ランプに対する温白色蛍光ランプの等価 的な明るさを与える輝度比は, 各々 $1.22,1.15,1.08$ であった。昼光色蛍光ランプに対する 3 波長域発光形 蛍光ランプの等価的な明るさを与える輝度比は, 各々 $1.03 ， 1.02 ， 1.01$ であった。輝度レべルが低いとその

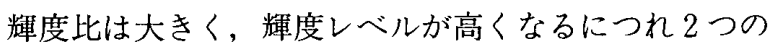
比較した光源間の差は小さくなって，既存の物体色を 考慮した実験とは異なる結果を得た。この結果は堀越 らの実験の結果と同じ傾向で, 明るさ知覚に及ぼす暗 所視の視感度の影響についても，今後検討を行いたい。 (2)実験光源種別を色温度で整理すると, 色温度が高くな るにつれ等価的な輝度比が減少する。輝度レベル別に 比較すると, 低い輝度レベルより高い輝度レベルで色 温度の違いによる差は小さくなった。

(3)視对象物の色や形状を考慮しない室内空間において, 光源の演色評価数と明るさの知敩の関係では, 明るさ 知覚に及ばす光源の演色性の効果だけでは表現できな
いものがあると考えられる。

実験方法に関して，次のよjな事項についての検討を 今後引きつづき行いたい。

(1)本実験では，前の条件の残像をなくすために 2 分間の 暗順応をさせたが，その効果については不明なので, さらに検討をする必要があると考えられる。

(2)本実験は，低い輝度レベルに順応させた後，明るさを 判断する調整法によったが, 上昇系列と, 下降系列を 交互に用いた心理測定法による検討も行う必要がある と考えられる。

注

予備実験として 2 名の被験者を用い20分間の暗順応をさせた 結果と 2 分間の暗順㐫をさせた結果とでは，あまり差は見られ

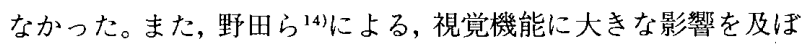
している「瞳孔径が条件提示前の状態に回復するまでには，ほ ぼ1 分間程度の時間を要するようである」という報告もあるの で，2 分間で行った。

\section{引用文献}

1) Aston, S.M., Bellchambers, H.E, : Illumination, colour rendering and visual clarity, Lighting Res. Technol. Vol. 1, No. 4, pp.259-261, 1969

2) 中村 洋, 比嘉後太郎, 沖 允人, 稲坦卓造: 蛍光灯の光 の色と明るさ感に関する研究, 日本色彩学会誌, Vol. 4, No. 3, pp. $30-31,1980$

3) W.A. Thornton/E. Chen: What is visual clarity, J. Illum. Engng. Soc. Vol. 7, No. 2, pp.85-94, 1978

4) W.B. Delancey/P.C. Hughes/J.F. Mcnelis/J.F. Sarver/ T.F. Soules: An examination of visual clarity with high colour rendering fluorescen light sources, J. Illum. Engng. Soc. Jan. pp.74-84, 1978.

5）納谷嘉信, 橋本健次郎：光源の演色性による明るさ感と配 色の目立ち感情の関連, 日本照明学会誌, Vol. 70, No. 2, pp.56-61, 1986

6) 日本照明学会：照明用語事典, オーム社, p1, 1977

7) 河合 悟: 明るさ, 日本照明学会誌, Vol. 69 , No. 9, pp.495 $-500,1985$

8) Flynn, J.E., Spencer, T.J. : The effects of light source color on user impression and satisfaction, J. Illum. Engng. Soc. April, pp.167-179, 1977

9）堀越哲美, Tiller, D.K. : 明るさ知覚に及ぼす光源の波長分 布と暗順応輝度の影響, 日本建築学会大会学術講演梗概集, pp.1163-1164, 1993

10) Berman, S.M.: Energy efficiency consequences of scotopic sensitivity, J. Illum. Engng. Soc. Vol. 21, No. 1, pp.3-14, 1992

11）湯尻 照：縮尺模型による照明条件の視環境評価に関する 実駼，日本照明学会誌，Vol. 61, No. 3, pp.43-50, 1977

12）乾 正雄：建築の色彩設計, 鹿島出版会, p54, 1976

13）納谷嘉信, 橋本健次郎：高演色性蛍光ランプの照明下での 明るさ感, 日本照明学会誌, Vol. 70, No. 2, pp.260-265, 1983

14）野田浩, 他 2 人:オフィス照明に関する研究その 4 目の順応状態がモデリングに及ぼす影響, 日本建築学会大 会学術講演梗概集（東海）, pp.1027-1028

(1995年12月10日原稿受理，1996年 6 月 20 日採用決定) 